\title{
PENGARUH MODEL PEMBELAJARAN RECIPROCAL TEACHING DENGAN TEKNIK MIND MAPPING TERHADAP KEMAMPUAN METAKOGNISI DAN AFEKTIF PADA KONSEP SISTEM SIRKULASI KELAS XI IPA DI SMA NEGERI 15 BANDAR LAMPUNG
}

(The Influence Reciprocal Teaching Model Of Learning With With Mind Mapping Technique On The Ability Of Metacognition And Affective On The Concept Of The Circulatory System In Grade XI IPA In Senior High School 15 Bandar Lampung)

\section{${ }^{1}$ Laila Puspita, ${ }^{2}$ Yetri, ${ }^{3}$ Ratika Novianti}

${ }^{1,2}$ Dosen Prodi Pendidikan Biologi Fakultas Tarbiyah dan Keguruan, Universitas Islam Negeri Raden Intan.Jl. H Endro Suratmin Sukarame-Bandar Lampung (0721)70326): Email lailapuspita@radenintan.ac.id

${ }^{3}$ Mahasiswi Prodi Pendidikan Fakultas Tarbiyah dan Keguruan, Universitas Islam Negeri Raden Intan. J1. H Endro Suratmin Sukarame-Bandar Lampung (0721)70326).

Diterima: 17 Mei 2017. Disetujui : 19 Juni 2017. Dipublikasikan: 29 Juni 2017

\begin{abstract}
Abstrak: Penelitian ini bertujuan untuk mengetahui pengaruh model pembelajaran resiprocal teaching dengan teknik mind mapping terhadap kemampuan metakognisi dan afektif pada konsep sistem sirkulasi kelas XI IPA SMA Negeri 15 Bandar Lampung. Metode penelitian yang digunakan pada penelitian ini adalah quasi experimental design. Desain penelitian yang digunakan pada quasi experimental ini adalah Pretest-Posttest Control Group Design. Penelitian dilaksanakan pada tanggal 3 September s/d 14 September 2016 di kelas XI IPA SMA N 15 Bandar Lampung dengan teknik pengambilan sampel adalah probability sampling type simple random sampling. Sampel ini terdiri 2 kelas yaitu kelas eksperimen (XI IPA 2) dan kelas kontrol (XI IPA 1). Berdasarkan hasil analisis data yang diperoleh uji hipotesis hasil belajar kemampuan metakognisi menggunakan uji Independent t-test Microsoft Exel 2007 dengan hasil $t_{\text {hitung }}$ $(1,713)>t_{\text {tabel (1.67155) }}$ dan uji hipotesis hasil belajar afektif menggunakan uji Independent $t$ test Microsoft Exel 2007 dengan hasil $t_{\text {hitung }(2,30905)}>t_{\text {tabel }}(1.67155)$. Berdasarkan hasil uji t, maka dinyatakan Hi diterima artinya, ada pengaruh model pembelajaran Reciprocal Teaching dengan teknik mindmapping terhadap kemampuan metakognisi dan afektif pada konsep sistem sirkulasi kelas XI IPA SMA Negeri 15 Bandar Lampung.
\end{abstract}

Kata kunci : Resiprocal Teachig, Mind Mapping, Metakognisi, Afektif

\section{PENDAHULUAN}

Pendidikan adalah proses yang sangat panjang dan keberhasilannya ditentukan berbagai faktor antara lain dari anak sebagai subyek pendidikan, orang tua dan guru sebagai pendidik, materi yang tepat, lingkungan yang mendukung serta berbagai model pembelajaran dan media yang tepat (Ratna Ningrum, 2005). Pendidikan memegang perananpenting dalam kehidupan,karena pendidikan merupakan proses perubahan sikap dan tingkah lakuseorang atau kelompok orang dalam usaha mendewasakan manusia melalui upaya pengajaran dan pelatiha (Muhibbin Syah, 2010).Pendidikan pada dasarnya membantu seseorang untuk mengetahui apa yang tidak diketahuinya.

Pendidikan di sekolah tidak terlepas dari kegiatan pembelajaran yang merupakan perencanaan secara sistematis yang dibuat oleh guru dalam satuan pelajaran. Menciptakan kegiatan pembelajaran yang mampu mengembangkan hasil belajar semaksimal mungkin tugas dan kewajiban guru. Oleh karena itu, 
seseorang guru memerlukan strategi penyampaian materi untuk mendesain pembelajaran yang dapat merangsang hasil belajar yang efektif dan efisien sesuai dengan situasi dan kondisinya. Berdasarkan hasil wawancara hasil belajar siswa masih relatif rendah karena yang mencapai Kriteria Ketuntasan Minimum (KKM) masih sebanyak 35 siswa dari total 117 siswa. Disamping itu juga dari observasi kekelas faktor yang mempengaruhi hasil belajar belajar siswa rendah adalah antara lain:Masih banyak siswa yang tidak memperhatikan guru dalam menjelaskan materi pelajaran yang disampaikan oleh guru, Sering kali ketika diberi kesempatan untuk bertanya oleh guru sementara siswa belum memahami materi yang disampaikan guru Siswa malas membaca karena materi terlalu banyak dan banyak istilah-istilah yang sulit untuk dipahami dan diingat.

Proses pembelajaran merupakan kegiatan interaksi antara guru dengan peserta didik dan komunikasi timbal balik yang berlangsung dalam situasi edukatif untuk mencapai tujuan belajar. Interaksi dan komukasi timbal balik antara guru dan peserta didik merupakan ciri dan syarat utama bagi kelangsungannya proses belajar mengajar (Nuryani Rustaman, 2003). Peran seorang guru dalam keberhasilan suatu proses pembelajaran sangatlah besar.

Seorang guru sebaiknya menggunakan metode atau model pembelajaran yang menunjang kegiatan belajar mengajar, yaitu dengan menggunakan model pembelajaran yang lebih menarik dan bervariasi yang diterapkan oleh guru dikelas sehingga diharapkan peserta didik akan menjadi aktif. Salah satunya yaitu dengan menggunakan model pembelajaran Resiprocal Teaching yang menggunakan teknik Mind Mapping.

Model pembelajaran Resiprocal Teaching dikembangkan oleh Palincsar dan Brown untuk mengajar siswa strategi-strategi kognitif serta membantu mereka dalam memahami bacaan (Jennifer R. Seymour, 2003). Palincsar dan Brown mencetuskan empat strategi Resiprocal Teachinga garmening katkan kemampuan membaca siswa yaitu: merangkum bacaan, mengajukan pertanyaan,memprediksi jawaban pemecahan masalah atau soal, mengklarifikasi atau menjelaskan istilah-istilah yang sulit dipahami atau dihafalkan (Petter EDoolittle, 2008).

Menurut Palinscar dalam buku warsono dan hariyanto, Resiprocal Teaching mengacu kepada aktivitas pengajaran yang terjadi dalam bentuk dialog antara guru dengan murid terkait segmen dari satu teks bacaan yang distrukturkan dalam empat strategi: membuat ringkasan, mengajukan pertanyaan, melakukan klarifikasi, dan melakukan prediksi. Selama pengajaran guru dan murid bertukar peran dalam memimpin dialog, sehingga menjadikan pengajaran ini suatu pengalaman pembelajaran kelompok yang menarik.Tentu saja teori scaffolding juga berperan menjadi landasan konsep Resiprocal Teaching (Warsono dan Hariyanto, 2012). Pernyataan tersebut didukung dengan Hasil penelitian Yesie Ema Yunita, penerapan pendekatan pengajaran terbalik (reciprocal teaching) untuk meningkatkan kemandirian belajar biologi siswa kelas VII-G SMPN 5 Karanganyar tahun pelajaran 2010/2011, pembelajaran dengan menggunakan pendekatan pengajaran Reciprocal Teaching dapat membantu siswa mencapai tujuan pembelajaran secara efektif dan efisien serta memungkinkan siswa untuk melakukan pembelajaran secaraaktif dan mandiri tanpa bergantung dengan guru, tidak hanya membaca dan mendengar tetapi juga memberikan kesempatan pada siswa untuk berlatih berdiskusi, berpartisipasi, 
bekerjasama, serta memecahkan masalah-masalah tertentu berkaitan dengan materi pembelajaran yang akhirnya dapat meningkatkan kemandirian belajar siswa.( Yesie Ema Yunita, 2010)

Resiprocal Teaching adalah model pembelajaran berupa kegiatan mengajarkan materi kepada teman. Pada model pembelajaran ini peserta didik berperan sebagai guru untuk meyampaikan materi kepada teman-temannya. Sementara itu guru lebih berperan sebagai fasilitator. Resiprocal Teaching adalah suatu model pembelajaran dimana peserta didik diberi kesempatan untuk mempelajari materi terlebih dahulu. Kemudian, peserta didik menjelaskan kembali materi yang dipelajarinya kepada peserta didik yang lain.

Reciprocal Teaching memiliki beberapa komponen utama, yaitu: Specifically, reciprocal teaching consists of three main components, (a) the teaching and learning of specific reading comprehension strategies, $(b)$ the dialogue between a instructor and studens where the instructor models why, when, and where touse these reading comprehension sstrategies, and (c) the appropriating of the role of the instructor by the students, that is students begin to model the reading comprehension strategies for otherstudents. (Peter E. Doolittle, 2006). Jika diartikan, reciprocal teaching mempunyai 3 komponen utama, yaitu: Strategi pengajaran dan pembelajaran yang spesifik dalam memahami teks, Adanya dialog diantara guru dengan siswa dimana guru memodelkan ketika menggunakan strategi dalam memahami teks, Pemeranan yang tepat yang dilakukan oleh guru kepada siswa, makasiswa dapat memulai model strategi pemahaman terhadap suatu teks kepada siswa yang lain.

Salah satu strategi untuk memahami materi pelajaran serta mudah memngingat peserta didik menggunakan Mind Mapping terhadap materi pelajaran yang sedang dipelajarinya. Dengan membuat Mind Mapping siswa dilatih untuk berimajinasi, berkreasi, mengorganisasi materi pelajaran dan memicu ide-ide orisinil yang berbeda dari yang telah ada. Mind Mapping merupakan cara mencatat yang kreatif, efektif, dan secara harfiah akan memetakan pikiran-pikiran kita. Peta pikiran dikembangkan oleh Tony Busan pada tahun 1970-an didasari pada riset tentang bagaimana cara kerja otak yang sebenarnya. Otak manusia sering mengingat informasi dalam bentuk gambar, simbol, suara, bentuk-bentuk, dan perasaan (Awwalia Maulvi laili, 2014).

Menurut Windura dalam Muhammad Chomsi Imaduddin, Mind Map adalah suatu teknis grafis yang dapat menyelaraskan proses belajar dengan cara kerja alami otak. Mind map melibatkan otak kanan sehingga proses pembuatannya menyenangkan, dan mind map merupakan cara paling efektif dan efisien untuk memasukkan, menyimpan,dan mengeluarkan data dari otak kita (Muhammad Chomsi Imaduddin, 2012).

Menurut Herdy dalam Sang Ayu Putu Diah Geminastiti Mind Mapping memadukan dan mengembangkan potensi kerja otak yang terdapat didalam diri seseorang. Dengan adanya keterlibatan kedua belahan otak maka akan memudahkan seseorang untuk mengatur dan mengingat segala bentuk informasi, baik secara tertulis maupun secara verbal. Adanya kombinasi warna, simbol,bentuk dan sebagainya memudahkan otak dalam menyerap informasi yang diterima. Mind mapping yang dibuat oleh siswa dapat bervariasi setiap 
hari. Hal ini disebabkan karena berbedanya emosi dan perasaan yang terdapat dalam diri siswa setiap harinya. Suasana menyenangkan yang diperoleh siswa ketika berada diruang kelas pada saat proses belajar akan mempengaruhi penciptaan peta pikiran (Sang Ayu Putu Diah Geminasti, 2012).

Mind Map akan membantu siapapun dalam meningkatkan kecepatan berpikir, memberikan kelenturan tidak terbatas, dan menjelajah jauh dari pemikiran sendiri. Mind Map dapat membantu kita dalam sangat banyak hal. Beberapa diantaranya yaitu: Merencana, Berkomunikasi, Menjadi lebih kreatif, Menghemat waktu, Menyelesaikan masalah, Memusatkan perhatian, Menyusun dan pikiran-pikiran, Mengingat dengan lebih baik, Belajar lebih cepat dan efisien. (Awwalia Mulvi Laili, 2004). Dapat disimpulkan bahwa Mind Map dapat bermanfaat untuk menggali pengetahuan siswa, membuat perencanaan kegiatan, memudahkan siswa memahami konsep sehingga tercipta pembelajaran bermakna dan kreativitas siswa dikembangkan oleh guru. Pernyataan tersebut didukung juga dengan hasil penelitian Yustina, dkk., dalam skripsinya yang berjudul "Penerapan Teknik Mind Mapping Dalam Strategi Quantum Learning Untuk Meningkatkan Motivasi Dan Hasil Belajar Biologi Siswa Kelas XIIPA2 SMA Nurul Falah Pekan baru Tahun 2009/2010". Dapat disimpulkan dari hasil penelitiannya yaitu meningkatnya hasil rata-rata skor hasil belajar dan motivasi belajar siswa setelah belajar dengan menggunakan Teknik Mind Mapping Dalam Strategi Quantum Learning. Selain itu juga daya serap siswa terhadap pelajaran meningkat pada siklus dua dibandingkan dari siklus satu. (Yustina,dkk., 2010)

Adapun Kelebihandan Kekurangan Mind Mapping Menurut Sinulingga dan Josevina, yaitu: (1) permasalahan yang disajikan terbuka, (2) Siswa berkelompok untuk menanggapi, (3) Dapat melatih siswa untuk saling bekerjasama dalam diskusi, (4) sangat cocok untuk mengulang kembali pengetahuan awal siswa. Kelemahan Mind Mapping yaitu: (1) banyak membutuhkan waktu, (2) sulit untuk mengalokasikan waktu, (3) Tuntutan bagi siswa terlalu membebani. (Sinulingga K dan Nadeak J, 2013).

Banyak diketahui bahwa faktor internal lebih dominan dalam menentukan hasil belajar. Hasil belajar dibagi menjadi tiga ranah yaitu ranah kognitif, psikomotorik, dana afektif. Dari ketiga ranah hasil belajar tersebut, ranah kognitiflah yang paling banyak dinilai para guru disekolah (Nana Sudjana, 2009). Beberapa faktor internal yang mempengaruhi hasil belajar adalah kemampuan metakognisi dan afektif.

Kemampuan metakognisi adalah kesadaran berpikir tentang apa yang diketahui dan apayang tidak diketahui. Dalam konteks pembelajaran, siswa mengetahui bagaimana untuk belajar, mengetahui kemampuan dan modalitas belajar yang dimiliki, dan mengetahui strategi belajar terbaik untuk belajar efektif. Metakognisi memainkan peranan yang penting dalam proses pembelajaran Halini didukung dari hasil penelitian Brown (1978), Rahman dan Philips (2006), yang menemukan bahwa kemampuan metakognisi merupakan kemampuan yang berkontribusi cukup tinggi dalam pencapaian hasil belajar siswa. Siswa yang mempunyai kemampuan metakognisi baik dapat menemukan gaya kognitif yang sesuai dengan karakternya dalam menyelesaikan proses belajar (Isnaini Maratus Sholihah, 2012).

Rahman dan Philips menemukan bahwa kemampuan metakognisi 
kemampuan yang berkontribusi cukup tinggi dalam pencapaian hasil belajar siswa. Siswa yang dapat menemukan gaya kognitif yang sesuai dengan karakternya dalam menyelesaikan proses belajar (Usman Mulbar, 2008). Berdasarkan uraian diatas maka dapat disimpulkan bahwa kemampuan metakognisi adalah cara mengatur proses berfikir diri sendiri tentang apa yang diketahui dan yang tidak diketahuinya yang merupakan pengetahuan yang diperoleh siswa tentang kognitif. Selain itu metakognisi adalah pengetahuan tentang strategi kerja yang baik untuk belajar dan bagaimana serta kapan menggunakan keterampilan dan strategi tersebut.

Menurut Gregory Scraw and Rayne Sperling Dennison metakognisi sebelumnya telah dibedakan antara dua komponen utama yaitu knowledge of cognition (pengetahuan kognisi) dan regulasi of cognition (peraturan kognisi). Dalam pengetahuan metakognisi terdapat tiga sub proses yang memfasilitasi aspek reflektif dari metakognisi yaitu : pengetahuan deklaratif, pengetahuan procedural, pengetahuan kondisional. Sedangkan peraturan kognisi terdapat lima komponen sub proses yang memfasilitasi aspek kontrol belajar antara lain : planning, menegement informasi, pemantauan, debugging strategi, evaluasi (Schraw and Dennison, 1994).

Definisi operasional dari kategori komponen sebagai berikut Pengetahuan kognisi (Knowledge of cognition): Pengetahuan Deklaratif adalah pengetahuan tentang keterampilan seseorang, sumber daya intelektual, dan kemampuan sebagai seorang pelajar. Pengetahuan Prosedural adalah pengetahuan tentang bagaimana menerapkan prosedur pembelajaran. Pengetahuan Kondisional adalah knowledge obaut when and why to use learning procedure (mereka tahu kapan dan bagaimana menggunakan pengetahuan deklaratif dan procedural). Sedangkan peraturan Kognisi (regulasi of Cognition) Planning adalah perencanaan, penetapan tujuan, danmengalokasikan sumber daya sebelum belajar. manajemen informasi adalah keterampilan dan Pengembangan strategi urutan digunakan on-line untuk memproses informasi lebih efisien (pengorganisasian, menguraikan, meringkas, selektif fokus). Pemantauan adalah penilaian seseorang belajar atau Pengembangan strategi penggunaan. Debugging adalah Strategi yang digunakan untuk memperbaiki pemahaman dan kinerja kesalahan. Evaluasi adalah analisis kinerja dan strategi efektivitas setelahpembelajaran. (Schraw and Dennison, 1994).

Selain kemampuan metakognitif ada pula kemampuan efektif, aspek afektif belum memper oleh perhatian seperti pada keduaaspek lainnya.Masalahafektif merupakan halyang penting namun implementasinya masih kurang, karena merancangpencapaiantujuan pembelajaran afektif tidak semudah seperti pembelajarankognitif.Penilaian hasil belajar afektif kurang mendapat perhatian dari guru. Para guru lebih menilai ranah kognitif semata- mata. Sekalipun bahan pelajaran berisi ranah kognitif ranah afektif harus menjadi bagian integral dari bahan tersebut dan harus nampak dalam proses belajar dan hasil belajar yang dicapai oleh siswa (Nana Sudjana, 2009).

Ranah afektif adalah ranah yang berkaitan dengan sikap dan nilai. Ranah afektif mencakup watak perilaku seperti perasaan, minat, sikap, emosi, dan nilai. Beberapa pakar mengatakan bahwa sikap seseorang dapat diramalkan perubahannya bila seseorang telah memiliki kekuasaan kognitif tingkat tinggi. Tipe hasil belajar afektif tampak pada siswa dalam berbagai tingkah laku seperti 
perhatiannya terhadap pelajaran, disiplin, motivasi belajar, menghargai guru dan teman sekelas, kebiasaan belajar dan hubungan sosial. Sekalipun bahan pelajaran berisi ranah kognitif, ranah afektif harus menjadi bagian intregal dari bahan tersebut, dan harus tampak dalam proses belajar dan hasil belajar yang dicapai oleh siswa. Oleh sebab itu, penting dinilai hasil-hasilnya (Nana Sudjana, 2009).

Perumusan tujuan instruktusional pada kawasan afektif tidak berbeda jauh bila dibandingkan dengan kawasan kognitif tetapi dalam mengukur hasil belajarnya jauh lebih sukar karena menyangkut kawasan sikap dan apresiasi. Selain itu, kawasan afektif sulit dicapai pada pendidikan formal karena prilaku yang nampak dapat diasumsikan timbul akibat kekakuan aturan, disiplin, belajar, waktu belajar, tempat belajar dan norma-norma lainnya (Martinis Yamin, 2012).

Devinisi operasional dari ranah afektif adalah Reesiving/Attending, Responding atau jawaban, Valuing ( penilaian), Organisasi, Karakteristik nilai atau internalisasi nilai. Ada beberapa jenis ranah afektif sebagai hasil belajar. Kategori dinilai dari tingkat dasar atau sederhana sampai tingkat yang kompleks. Reesiving/Attending. Yakni semacam kepekaan dalam menerima rangsangan (stimulus) dari luar yang datang kepada siswa dalam bentuk masalah, situasi, gejala dll. Dalam tipe ini termasuk kesadaran, keinginan menerima stimulus, kontrol dan seleksi gejala atau rangsangan dari luar.Responding atau jawaban yakni reaksi yang diberikan oleh seseorang terhadap stimulus yang datang dari luar. Hal ini mencakupketepatan reaksi, perasaan, keopuasan dalam menjawab stimulus dari luar yang datang kepada dirinya.Valuing ( penilaian) berkenaan dengan nilai kepercayaan terhadap gejala atau stimulus tadi. Dalam evaluasi ini termasuk didalamnya kesediaan menerima nilai, latar belakang atau pengalaman untuk menerima nilai dan kesepakatan terhadap nilai tersebut.Organisasi, yakni pengembangan dari nilai kedalam suatu sistem, organisasi,termasuk hubungan satu nilai dengan nilai lain pemantauan dan prioritas nilai yang telah dimilikinya. Yang termasuk kedalam organisasi ialah konsep tentang nilai, organisasi sistem nilai, dll.Karakteristik nilai atau internalisasi nilai, yakni keterpaduan semua sistem nilai yang telah dimiliki seseorang, yang mempengaruhi pola kepribadian dan tingkah lakunya. Kedalamnya termasuk keseluruhan nilai dan karakteristiknya. (Nana Sudjana, 2009)

Untuk menyikapi permasalahan yang berkaitan dengan kondisi kegiatan pembelajaran, maka perlu upaya perbaikan dan inovasi dalam proses pembelajaran. Salah satu alternatif yang dapat mengatasi permasalahan dalam pendidikan adalah guru perlu melakukan pembenahan dalam proses pembelajarannya, memposisikan guru sebagai perancang dan organisator pembelajaran sehingga siswa memperoleh kesempatan untuk memahami dan memaknai melalui aktivitas belajar tersebut.

\section{METODE PENELITIAN}

Waktu penelitian dilaksanakan pada 3 - 14 september di SMA Negeri 15 bandar Lampung kelas XI IPA semester genap Tahun Pelajaran 2015/2016. Metode penelitian yang digunakan dalam penelitian ini adalah metode eksperimen, yaitu kuasi eksperimen. Pada penelitian ini peneliti menggunakan 
desain penelitian pretest-posttest Control Group Design (Sugiono, 2010). Desain ini terdapat dua kelompok kelas yang dipilih secara random, kemudian diberi pretest untuk mengetahui keadaan awal adakah perbedaan antara kelompok eksperimen dan kelompok kontrol. Pada kelas eksperimen menggunakan model pembelajaran reciprocal teaching dengan teknik mind mapping, sedangkan pada kelas kontrol menggunakan model konvensional berupa metode ceramah dan tanya jawab.

Variabel yang digunakan dalam penelitian ini ada dua variabel yaitu variabel yang mempengaruhi (variabel bebas) yaitu model pembelajaran reciprocalteaching dengan teknik mind mappingdan variabel yang dipengaruhi (variabel terikat) yaitu kemampuan metakognisi dan afektif.

Populasi yang diambil dalam penelitian ini adalah seluruh peserta didik kelas XI IPA SMA N 15 Bandar Lampung tahun pelajaran 2016/2017. dengan teknik random sampling. Random sampling adalah teknik penentuan sampel dengan secara acak. Sampel dalam penelitian ini yaitu:Kelas XI IPA 1 sebagai kelas kontrol dan Kelas XI IPA 2 sebagai kelas eksperimen. Adapun teknik pengumpulan data yang peneliti gunakan dalam penelitian ini adalah sebagai berkut: Angket dalam penelitian ini digunakan peneliti untuk mengetahui tingkat kemampuan metakognisi dan afektif pada peserta didik, Observasi dilakukan peneliti untuk mengamati fenomena-fenomena yang terjadi selama proses pembelajaran berlangsung sehingga peneliti memperoleh data yang akan membantu peneliti untuk mengetahui masalah apa saja yang terjadi selama pembelajaran tersebut. Observasi yang dilakukan merupakan observasi nonpartisipan dan berupa observasi tidak terstruktur, dokumentasi ini dilakukan peneliti untuk mengumpulkan data-data yang diperlukan peneliti sebagai pendukung atau penguat data-data sebelumnya, tes yang digunakan peneliti adalah untuk menentukan data kuantitatif tentang kemampuan metakognisi peserta didik setelah menerima perlakuan, apakah ada perbedaan yang signifikan antara kelompok eksperimen dan kelompok kontrol. Pengukuran ini melalui tes uraian kemampuan metakognisi.

Uji Coba Instrumen Penelitian yang dilakukan dengan menggunakan uji yaitu: Validitas Instrumen, reliabilitas, uji tingkat kesukaran, uji daya pembeda. Tekhnik analisis data pada penelitian ini menggunakan Nilai Gain Ternomalisasi sedangkan untuk uji prasyarat menggunakan uji normalitas uji homogenitas, uji hipotesis menggunakan uji-t.

\section{PEMBAHASAN}

Berdasarkan hasil uji hipotesis dengan program Microsoft Exel 2007 dengan $t_{\text {Hitung (1,713) }}>t_{\text {Tabel }(1,67155)}$ hasil belajar kemampuan metakognisi dan hasil belajar afektif $\mathrm{t}_{\text {hitung }(2,30905)}>\mathrm{t}_{\text {table (1,67155) }}$ maka ada pengaruh model pembelajaran Resiprocal Teaching dengan teknik Mind Mapping terhadap kemampuan metakognisi dan afektif peserta didik kelas XI IPA di SMA N 15 Bandar Lampung. Selama penelitian pembelajaran Biologi kelas XI IPA khususnya IPA 1 dan IPA 2 dilaksanakan 3 kali pertemuan dalam 2 kali dalam seminggu setiap pertemuan 2 jam pelajaran dimana satu jamnya 45 menit. Kelas XI IPA 1 sebagai kelas Eksperimen pada hari sabtu pukul 10.45-12.15 dan hari rabu pada pukul 08.45- 10.45 terpotong istirahat 30 menit. Kelas XI IPA 2 sebagai kelas kontrol pada hari senin pukul 0845- 10.45 terpotong istrahat dan hari rabu pikul 12.45- 
14.15 berdasarkan jadwal tersebut penelitian dilaksanakan dengan materi ajar sistem sirkulasi.

Proses pembelajaran yang dilakukan kelas eksperimen yaitu dengan menggunakan model pembelajaran Resiprocal Teaching dengan teknik Mind Mapping. Pembelajaran dimulai dari guru menjelaskan tujuan pembelajaran. Guru mengkondisikan kelas untuk melaksanakan model Resiprocal Teaching dengan teknik Mind Mapping yang dilakukan dengan cara diskusi kelompok. Kegiatan pembelajaran dengan cara berkelompok untuk bekerja sama saling membantu satu sama lain. Guru memberikan lembar teks materi kepada setiap kelompok dan setiap kelomponk mengerjakan tugasnya masing-masing. Tugas yang harus mereka kerjakan dalam setiap kelompok yang pertama yaitu merangkum materi sistem sirkulasi dalam bentuk Mind Mapiing dikarton. kedua mereka harus mempuat pertanyaan dari lembar teks yang dibagikan. Ketiga mereka harus membuat prediksi jawaban dari pertanyaan yang mereka buat. Keempat mereka mengklasifikasin hal-hal yang sulit dimengerti dari teks bacaan yang sudah dibagikan. Kegiatan yang dilakukan setelah berdiskusi yaitu setiap kelompok menunjuk perwakilan untuk mempresentasikan hasil diskusi kelompoknya kedepan kepada temen-temannya yang lain.

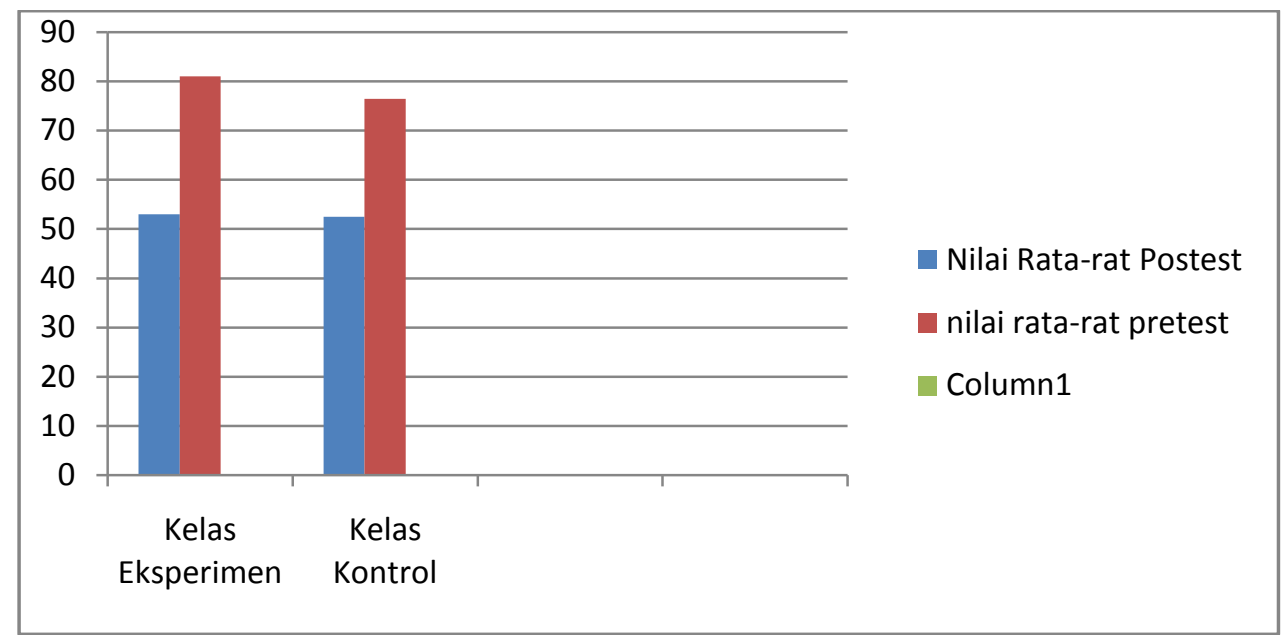

Gambar 1. Hasil Belajar Kemampuan Metakognisi

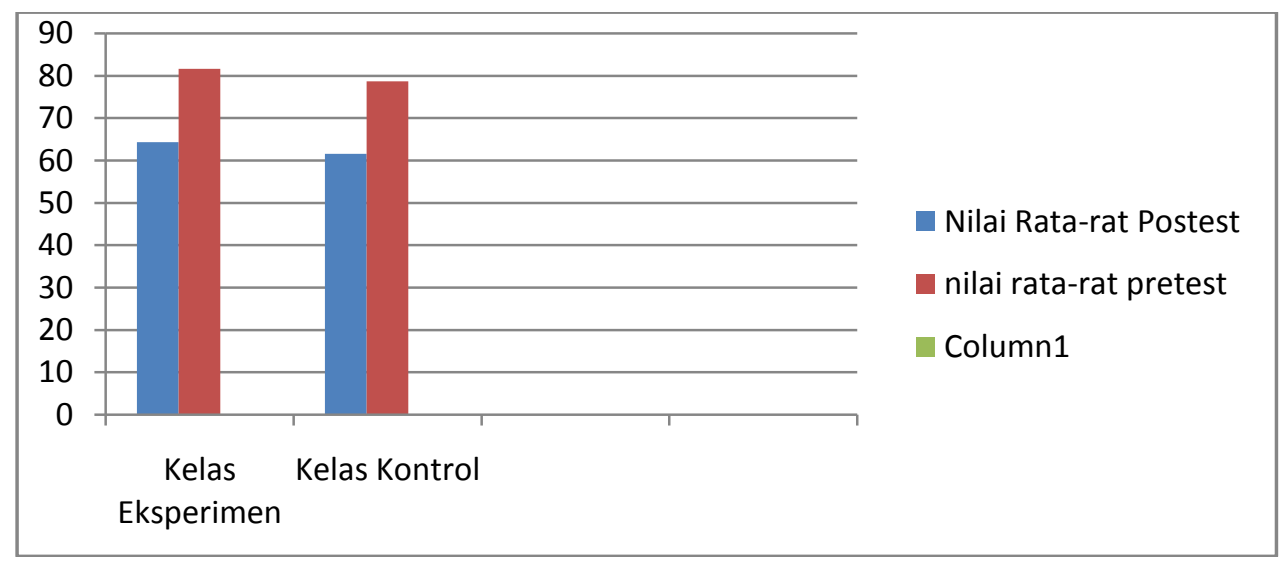

Gambar 2. Hasil Belajar Kemampuan Afektif 
Hasil penelitian menunjukkan bahwa rata-rata nilai akhir metakognisi dan afektif peserta didik baik kelas eksperimen maupun kelas kontrol mengalami peningkatan.Pada kelas eksperimen proses pembelajaran menggunakan model pembelajaran Resiprocal Teaching dengan Teknik Mind Mapping diperoleh ratarata nilai tes awal metakognisi adalah 52.96 meningkat pada tes akhir sebesar 81.00 , sedangkan pada kelas kontrol rata-rata nilai tes awal yang diperoleh oleh kelas ini adalah 52.51 nilainya meningkat pada tes akhir yakni sebesar 76,45. Pada kemampuan afektif nilai rata-rata tes awal pada kelas eksperimen adalah 64.32 dan meningkat pada tes akhir sebesar 81.62, sedangkan pada kelas kontrol ratarata nilai tes awal adalah 61.57 dan meningkat pada tes akhir sebesar 78.72. Dari hasil tersebut, dapat diketahui bahwa penggunaan model pembelajaran Resiprocal Teaching dengan teknik Mind Mapping dapat mempengaruhi nilai kemampuan metakognisi dan afektif peserta didik kelas XI IPA SMA Negeri 15 Bandar Lampung pada materi sistem sirkulasi.Penjelasan diatas menunjukkan bahwa terdapat perbedaan perolehan nilai pada kedua kelas. Perbedaan tersebut disebabkan karena saat pembelajaran, guru menggunakan model pembelajaran Resiprocal Teaching dengan teknik Mind Mappingyang dapat membuat peserta didik lebih aktif, kreatif dan antusias dalam belajar dan peserta didik akan mendapatkan kemudahan dalam menerima dan memahami materi yang diajarkan karena terjadi timbal balik antara guru dan siswa. Selain itu, meningkatkan partisipati peserta didik melalui tulisan, ide sehingga sangat baik bagi siswa yang kurang berani mengungkapkan pertanyaan, keinginan, dan harapan-harapan melalui diskusi Resiprocal Teaching.

Keadaan ini menggambarkan bahwa meningkatnya hasil belajar siswa pada konsep Sirkulasi lebih baik dengan menggunakan model pembelajaran Resiprocal Teaching terintegrasi Mind Mapping, karena telah menunjukkan hasil yang lebih baik dibandingkan dengan tidak menggunakan model pembelajaran. Hal ini didukung hasil uji N-Gain pada kedua kelas, kelas ekperimen memperoleh peningkatan hasil metakognisi dan afektif yang lebih tinggi dibandingkan kelas kontrol. Hal tersebut dapat dilihat dari siswa yang memperoleh nilai N-Gain pada kelas eksperimen. Pada hasil metakognisi kelas eksperimen diperoleh sebanyak 10 memperoleh kategori tinggi, 18 siswa dalam kategori sedang, dan 2 siswa dalam kategori rendah , rata-rata kelas eksperimen lebih besar dari kelas kontrol yaitu 0,59. Pada kelas kontrol 3 siswa yang memperoleh kategori tinggi, 26 siswa yang memperoleh kategori sedang, dan 1 siswa dalam kategori rendah, rata-rata kelas kontrol lebih kecil dari kelas eksperimen, yaitu 0,51. Selain peningkatan pada metakognisi dapat dilihat juga peningkatan pada afektif yaitu diperoleh sebanyak 6 siswa yang memperoleh kategori tinggi, 18 siswa memperoleh kategori rendah, dan 6 siswa dengan kategori rendah dan diperoleh rata-rata $\mathrm{N}$ Gain pada kelas eksperimen sebanyak 0,51 dengan kategori sedang. Pada kelas kontrol diperoleh 21 siswa yang memperoleh kategori sedang, 9 siswa yang mendapat kategori rendah dan tidak ada yang memperoleh kategori tinggi denga rata-rata $\mathrm{N}$-gain yang didapat adalah 0,38 dengan kategori sedang.

Berdasarkan hasil diatas artinya kedua kelas tersebut memiliki kemampuan awal yang hampir sama pada kemampuan metakognisi yaitu kelas eksperimen 52,96 sedangkan pada kelas kontrol 52,51 dan pada afektif kelas eksperimen memperoleh rata-rata nilai 64,31 dan pada kelas kontrol 61,57 Setelah diberi perlakuan yang berbeda, kelas eksperimen yang diberi model pembelajaran 
Resiprocal Teaching terintegrasi MindMapping menunjukan hasil belajar yang lebih tinggi dibandingkan hasil belajar siswa dikelas kontrol yang tidak diberi perlakuan model pembelajaran. Hal tersebut dapat terjadi karena pada proses pembelajaran di kelas eksperimen diberi perlakuan dengan model pembelajaran Resiprocal Teaching terintegrasi Mind Mapping. Pembelajaran yang diperlakukan dengan model Resiprocal Teaching dengan teknik Mind Mapping dibandingkan dengan kelas yang tidak diberlakukan model memiliki hasil kemampuan metakognisi dan afektif yang berbeda sangat signifikan. Hal ini menunjukkan bahwa model Resiprocal Teaching terintegrasi Mind Mapping berpengaruh sangat signifikan terhadap kemampuan metakognisi dan afektif, dengan kata lain, penerapan model Resiprocal Teaching terintegrasi Mind Mapping memberikan pengaruh positif dan sangat kuat terhadap kemampuan metakognisi.

Peningkatan ini dapat dijelaskan bahwa model Resiprocal Teaching terintegrasi Mind Mapping memiliki kekuatan yang sangat tinggi untuk memberdayakan ketarampilan metakognisi. Model Resiprocal Teaching memberi kesempatan lebih banyak kepada siswa untuk mencari informasi di berbagai sumber belajar dan kebebasan menggunakan berbagai media belajar untuk membangun pengetahuan sendiri,memungkinkan siswa untuk memperoleh pengalaman belajar yang lebih, seperti cara menyusun dan menjelaskan pikiranpikiran mereka, setelah mereka membaca dan mempelajari materi dengan mandiri kemudian dirangkum dengan menggunakan mind mapping, siswa juga lebih memahami dan mengingat materi poin-poin yang telah mereka rangkum sehingga memudahkan dalam merencanakan suatu bahasan dalam diskusi kelompok, membantu peneliti dalam mengkondisikan waktu, dan siswa dapat mengembangkan ide-ide yang kreatif dan imajinatif dalam membuat rangkuman mind map untuk memudahkan mereka memahami dan mempelajari materi yang telah didiskusikan. Selain merangkum siswa juga akan membuat pertanyaan dari materi yang telah dirangkum .Selain itu, dalam Model Resiprocal pada tahap kegiatan ketiga yaitu memprediksikan jawaban dari pertanyaan yang sudah dibuat, hal ini memaksa siswa untuk mencari informasi berbagai sumber belajar. Kegiatan ini membuat siswaa lebih aktif mencari solusi permasalahan sehingga siswa menjadi paham terhadap apa yang mereka kerjakan. Tahap terakhir dalam model Resiprocal yaitu mengkalasifikasikan hal-hal yang kurang atau tidak dipahami ini dapat menjadi solusi bagi siswa yang takut untuk bertanya untuk mengatasi kebingungannya. Pada model Resiprocal digabungkan dengan teknik Mind Mapping dimana Mind Mapping membantu otak manusia mengingat informasi dalam bentuk gambar, simbol, suara, bentuk-bentuk, dan perasaan. Mind Mapping menggunakan pengingat-pengingat visual dan sensorik dalam suatu pola dari ideide yang berkaitan seperti peta jalan yang digunakan untuk belajar, mengorganisasikan, dan merencanakan. Mind Mapping dapat memicu ide-ide orisionilbaru, berbeda dari yang telah ada sehingga dapat memicu ingatan dengan mudah. Ini jauh lebih mudah dibandingkan dengan metode mencatat tradisional, karena dapat mengaktifkan kedua belahan otak manusia, sehingga peta pikiran sering disebut pendekatan keseluruhan otak. Cara ini dapat mempermudah membuat catatan, menyenangkan, dan melatih kreativitas berpikir siswa.

Pengaruh model-model pembelajaran khususnya model Resiprocal Teaching terhadap peningkatan keterampilan metakognisi dan afektif menunjukkan bahwa proses pembelajaran yang berdasarkan penyelidikan atau 
pembelajaran yang berbasis konstruktivistik (yang mana pebelajar aktif mencari informasi dan membangun pengetahuan mereka) dapat menumbuhkan dan mengembangkan proses mengetahui dan proses berpikir mereka atau yang lebih dikenal dengan istilah metakognisi. Dengan kata lain bahwa, model Resiprocaldengan teknik Mind Mapping memiliki potensi besar untuk mengembangkan dan meningkatkan keterampilan metakognisi dan afektif. Keterampilan metakognisi dan afektif dalam pembelajaran tercermin dalam karya kooperatif kelompok kerja dalam menyusun laporan penyelidikan, saat mempresentasikan dan mendiskusikan tugas mereka di kelas, serta hasil tes atau evaluasi akhir penguasaan konsep setelah proses pembelajaran.

Seperti dalam penelitian Sinulingga dan Joseniva Nadeak tahun 2012 yang menyatakan bahwa dengan berdiskusi dalam kelompok, masing-masing anggota kelompok mendukung untuk saling memahami materi, keberhasilan setiap anggota kelompok adalah kewajiban masing masing anggota. Selain hal tersebut, strategi mind mapping menuntut siswa untuk lebih kreatif, siswa dilatih untuk berpikir secara menyeluruh menuliskan dan memahami kata kunci setiap cabang mind map. (Sinulingga K dan Nadeak J. 2013)

Hasil penelitian yang diperoleh sesuai dengan keunggulan Resiprocal Teaching dan Mind Mapping yang terdapat pada penelitian-penelitian sebelumnya. Misalnya Menurut Jennifer R.Seymour and Helena P. Osana (2003) dalam jurnalnya yang berjudul "Reciprocal Teaching procedures and principles: two teachers' developing understanding", bependapat bahwa strategi Reciprocal Teaching dapat membantu anak dalam mengingat pelajaran Biologi dan dapat membantu mereka dalam memahami bacaan, dengan melalui 4 tahapan yaitu; merangkum bacaan, mengajukan pertanyaan, memprediksi jawaban, mengklasiifikasi atau menjelaskan istilah-istilah yang sulit dipahami atau dihafalkan. (Jennifer R.Seymour and Helena P. Osana)

Seperti halnya pada penelitian Yesie Ema Yunita yang berjudul Penerapan Pendekatan Pengajaran Terbalik (Reciprocal Teaching) Untuk Meningkatkan Kemandirian Belajar Biologi Siswa KelasVii-G Smp N 5 Karanganyar Tahun Pelajaran 2010/2011. Pembelajaran dengan menggunakan pendekatan pengajaran terbalik (ReciprocalTeaching) dapat membantu siswa mencapai tujuan pembelajaran secara efektif dan efisien serta memungkinkan siswa untuk melakukan pembelajaran secara aktif dan mandiri tanpa bergantung dengan guru, tidak hanya membaca dan mendengar tetapi juga memberikan kesempatan pada siswa untuk berlatih berdiskusi, berpartisipasi, bekerjasama, serta memecahkan masalah-masalah tertentu berkaitan dengan materi pembelajaran yang akhirnya dapat meningkatkan kemandirian belajar siswa. (Yesie Ema Yunita. 2011)

Hasil penelitian menunjukkan bahwa pengaruh model pembelajaran Resiprocal Teaching terintegrasi Mind Mapping dapat dijadikan suatu pertimbangan dalam proses pembelajaran Biologi. Karena setiap siswa memiliki cara belajar yang berbeda untuk mencapai hasil belajar, dengan kemandirian belajar mereka dapat menambah dan mencari tahu apa saja yang mereka butuhkan dalam suatu jawaban dan untuk menambah wawasan mereka dalam memahami materi. Selain itu juga dengan cara meringkas materi menggunakan mind mapp dengan tepat, dapat memudahkan siswa dalam berkonsentrasi dan memudahkan memahami, menghafal, dan tidak membosankan. Dapat disimpulkan dari hasil penelitiannya yaitu meningkatnya hasil rata-rata kemampuan metakognisi dan 
afektif setelah belajar dengan menggunakan model Resiprocal Teaching dengan Teknik Mind Mapping . Kelas yang tidak diperlakukan dengan model apa- apa adalah kelas kontrol juga mengalami peningkatan tetapi lebih bsar kelas eksperimen, sehingga ada perbedaan hasil kemampuan metakognisi dan afektif yang signifikan antara kelompok eksperimen dan kelompok kontrol, hasil kemampuan metakognisi dan afektif kelompok eksperimen lebih tinggi dibandingkan kelompok kontrol. Kegiatan siswa membuat Mind Map dari buku yang baru dibacanya, akan meningkatkan pemahaman, ingatan, dan juga mind map tersebut dapat digunakan kelak dalam belajar menghadapi ujian, serta siswa menjadi lebih aktif dan kreatif dalam proses pembelajaran pelajaran biologi. Pembelajaran dengan model pembelajaran yang diintegrasikan dengan Mind Mapping, secara umum dapat menunjukkan pembelajaran yang lebih efektif dan dapat meningkatkan hasil kemampuan metakognisi dan afektif. Seperti halnya pada penelitian ini yang mengintegrasikan antara model ReciprocalTeaching dan Mind Mapping dapat menjadikan siswa belajar secara aktif, kreatif, imajinatif dan mandiri tanpa bergantung dengan guru, tidak hanya membaca dan mendengar saja, tetapi juga memberikan kesempatan pada siswa untuk berlatih membuat suatu rangkuman materi yang menarik dan mudah untuk mereka pahami, berlatih berdiskusi, berpartisipasi, bekerjasama, serta memecahkan masalah-masalah tertentu berkaitan dengan materi pembelajaran yang akhirnya dapat meningkatkan hasil hasil kemampuan metakognisi dan afektif.

\section{KESIMPULAN DAN SARAN}

Berdasarkan hasil penelitian diatas dapat disimpulkan bahwa "Ada pengaruh model pembelajaran Resiprocal Teaching dengan teknik Mind Mapping terhadap kemampuan metakognisi dan afektif pada konsep sistem sirkulasi kelas XI IPA di SMA N 15 Bandar Lampung semester ganjil Tahun Pelajaran 2016/2017.

Penelitian ini dapat menjadi saran bagi Sekolah guna meningkatkan mutu dan kualitas pendidikan di sekolah, bagi pendidikhendaknya tidak terfokus pada satu cara dalam mengajar mempertimbangkan setiap karakteristik peserta didiknya dan tidak menyamaratakan kemampuan peserta didik karena setiap peserta didik memiliki keunikannya masing-masing. Bagi peneliti Laindisarankan untuk penelitian selanjutnya agar peneliti benar-benar memahami bagaimana konsep pembelajaran Resiprocal Teaching dengan Teknik Mind Mapping sehingga penelitian dapat dilakukan dengan maksimal dan mendapatkan hasil yang memuaskan.

\section{DAFTAR PUSTAKA}

Awwalia Maulvi laili. 2014. Pengaruh Model Pembelajaran Resiprocal Teaching Terintregasi Mind Mapping terhadap Hasil Belajar Pada Konsep Sistem Sirkulasi. ( Skripsi Pendidikan UIN Syarif Hidayatullah).

Isnaini Maratus Sholihah. 2012. Kekuatan dan Arah Kemampuan Metakognisi, Kecerdasan verbal dan kecerdasan Intrerpersonal Hubungannya Dengan Hasil Belajar Biologi Siswa Kelas XI IPA SMA N 3 Sukoharjo (Jurnal Pendidikan UNS, No 1, Vol 4. 
JenniferR.Seymour,dkk., 2003.Reciprocal Teaching procedures and principles: two teachers 'developing understanding, journal Teaching and Teacher Education,19.

Ningrum, Ratna. 2005. Mendidik Secara Cerdik. Solo : Tiga Serangkai.

Martinis Yamin. 2012. Desain Baru Pembelajaran Konstruktivistik. Jakarta : Referensi.

Muhammad Chomsi Imaduddin.2012.EfektifitasMetodeMind MappingUntuk meningkatkanPrestasi Belajar Fisikapada Siswa Kelas VIII. Humanitas, Vol.IXNo.1 Januari 2012.

PetterEDoolittle, dkk. 2006. Reciprocal Teaching for Reading Comprehension in Higher Education: A Strategy for Fostering the Deeper Understanding of Texts, vol. 17.

Rustaman, Nuryani Y. Strategi Belajar Mengajar Biologi (Bandung : Universitas Pendidikan Indonesia, 2003.

Sang Ayu Putu Diah Geminasti, dkk., Pengaruh Model Pembelajaran Kooperatif Mind Mapping Berbantuan Media Gambar Terhadap Hasil Belajar IPS Siswa Kelas V Gugus VII Kecamatan Gianyar, Jurnal Mimbar PGSD Universitas Pendidikan Ganesha Jurusan PGSD (vol,2,No.1)

Sinulingga K dan Nadeak J. 2013. Pengaruh Model Pembelajaran Kooperatif Tipe STAD Berbasis Mind Mapping Terhadap Hasil Belajar Siswa Pada Konsep Bunyi di Kelas VIII SMP Negeri 3 Tebing Tinggi, Jurnal Online Pendidikan Fisika, ISSN 1301-7651, h. 43.

Schraw, G \& Dennison, R.S. 1994. Assessing Metakognitive Awareness. Conteporary Educational Psychology, 19.

Sudjana, Nana. 2009. Penilaian Hasil Proses Belajar Mengajar. Bandung: Remaja Rosdakarya.

Sugiyono. 2010. Metode Penelitian Pendidikan Pendekatan Kuantitatif, Kualitatif , dan R\&D. Bandung : Alfabeta.

Syah, Muhibbin. 2010. Psikologi Pendidikan dengan pendekatan Baru .Bandung: Remaja Rosdakarya.

Usman Mulbar.2008. Aktivitas dalam Pembelajaran Matematika Realistik di Sekolah Menengah Pertama(Perangkat PMR yang Secara Eksplisit Melibatkan Metakognisi Siswa). Makassar : Universitas Negeri Makassar.

Warsonodan Hariyanto.2012.Pembelajaran AktifTeori danAsesmen. Bandung: Remaja Rosdakarya.

Yesie Ema Yunita. 2010. Penerapan Pendekatan Pengajaran Terbalik (Reciprocal Teaching) Untuk Meningkatkan Kemandirian Belajar Biologi Siswa Kelas Vii-G Smp N 5 Karanganyar Tahun Pelajaran 2010/ 2011 (Pendidikan Biologi Volume 3, Nomor 2, Mei 2011, FKIP UNS).)

Yustina,dkk.2010."PenerapanTeknikMindMappingDalamStrategiQuantumLearni ngUntuk MeningkatkanMotivasiDanHasil BelajarBiologi SiswaKelas XI IPA2SMANurulFalah Pekanbaru”,Skripsi Universitas Riau,Riau. 